\title{
ICTOPIЯ
}

\section{History of weaving in Azerbaijan}

\section{Shahla Mammadova, Azerbaijan State Agrarian University}

One of the interesting part of craftsmanship is weaving and its' history is very ancient. The article was dedicated to history of weaving in Azerbaijan. Archaeological materials which concern to weaving were unearthed during the excavations last decade are very significant for the history of craftsmanship. From Neolothic to Medieval period weaving had been developed and catched its' industrial high. Archaeological materials give us an opportunity to describe a life of weavers in ancient times in Azerbaijan. According to weaving, abundance of raw material reserves in Azerbaijan territories have rich development since ancient times.First of all, there are included wild technical plants as well as lagh, linen, hemp mallow, nettle and etc. Along with this, development of cattle-breeding especially weaving and existence of main raw material reserves,wool should be emphasized. According to researches, early step of weaving was connected with simple technical habits in weaving field. Archaeologists suppose that bone tools with sharp edge which were found at "Firuz" camp in Qobustan of the Mesolithic period are related to elementary weaving. So that, actually we can't deny the fact of appearance of initial habits in weaving field before the Neolithic period.Afterwards, habits obtained in weaving stimulated formation of weaving in the Neolithic period.In the Neolithic period and in the Eneolithic period that had replaced it, weaving became one of the significant fields for home craftsmen. As is known, at that time fields as home craftsmen's stoneprocessing, boneprocessing, ceramics production, leather and peltprocessing, metalprocessing were spread widely. Actually, development of weaving was closely connected with most of above said fields of craftsmanship. There was defined existance of traces of mattings made from clay and reed at Kultepe I near to Nakhchivan city and Alikomektepesi monument in Mugan. There are remains of textile and matting on sceletons and on surface of clay pots in opened ground graves. In addition, there are found remains of mattings on clay floors of buildings of Alikomektepesi settlement.

Keywords: weaving, archaeology, Kultepe, Azerbaijan, Caucasian Albania, antique period, early medieval period, medieval period

\section{Історія ткацтва в Азербайджані \\ Шахла Мамедова, Азербайджанський державний аграрний університет}

Однією з цікавих частин майстерності є ткацтво, і його історія дуже давня. Стаття була присвячена історії ткацтва в Азербайджані. Археологічні матеріали, що стосуються ткацтва, були знайдені під час розкопок минулого десятиліття, $є$ дуже значущими для історії ремісництва. Від неолотичного до середньовічного періоду ткацтво було розвинене і досягло його промислового максимуму. Археологічні матеріали дають нам можливість описати життя ткачів у давні часи в Азербайджані. За даними ткацтва, велика кількість запасів сировини на азербайджанських територіях має багатий розвиток з найдавніших часів. Перш за все, сюди входять дикорослі технічні рослини, а також ягня, полотно, конопляна мальва, кропива та ін. Поряд 3 цим слід наголосити на розвитку тваринництва, особливо ткацтва та існування основних запасів сировини, вовни. Згідно з дослідженнями, ранній крок ткацтва був пов'язаний з простими технічними звичками в галузі ткацтва. Археологи припускають, що кістяні знаряддя з гострим краєм, знайдені в таборі «Фіруз» у Кубустані періоду мезоліту, пов'язані з елементарним ткацтвом. Отже, насправді ми не можемо заперечувати факт появи початкових звичок у ткацькому полі до періоду неоліту. Згодом звички, отримані в ткацтві, стимулювали формування ткацтва в період неоліту. У період неоліту та в енеоліт, який його замінив, ткацтво стало одним із важливих напрямків для домашніх майстрів. Як відомо, у той час були широко розповсюджені такі галузі, як обробка каменю домашніми майстрами, обробка кісток, виробництво кераміки, обробка шкіри та шкур, обробка металу. Власне, розвиток ткацтва був тісно пов'язаний з більшістю згаданих вище галузей ремісництва. Виявлено наявність слідів зв'язок із глини та очерету в Культепе I поблизу міста 
Нахчиван та пам'ятника Алікомектепесі в Мугані. На скелетах та на поверхні глиняних горщиків у розкритих грунтових могилах є залишки текстилю та рогожки. Крім того, на глиняних підлогах будівель поселення Алікомектепесі знайдені залишки матов.

Ключові слова: ткачтво, археологія, Культепе, Азербайджан, Кавказька Албанія

\section{История ткачества в Азербайджане}

\section{Шахла Мамедова, Азербайджанского государственного аграрного университета}

Одна из интересных частей мастерства - ткачество, его история очень древняя. Статья была посвящена истории ткачества в Азербайджане. Археологические материалы, относящиеся к ткачеству, были обнаружены во время раскопок последнего десятилетия, и имеют большое значение для истории ремесленничества. От неолотики до Средневековья ткачество было развито и достигло своего промышленного пика. Археологические материалы дают нам возможность описать быт ткачей в древние времена в Азербайджане. Согласно ткацкому делу, богатые запасы сырья на территориях Азербайджана имеют богатое развитие с древних времен. В первую очередь это дикорастущие технические растения, а также лаг, лен, мальва конопля, крапива и др. Наряду с этим следует отметить развитие животноводства, особенно ткачества, и наличие основных запасов сырья - шерсти. Согласно исследованиям, ранний этап ткачества был связан с простыми техническими навыками в области ткачества. Археологи предполагают, что костяные орудия с острой кромкой, найденные в лагере «Фируз» в Гобустане периода мезолита, связаны с элементарным плетением. Таким образом, фактически мы не можем отрицать факт появления первоначальных навыков в области ткачества еще до неолита. Впоследствии навыки ткачества стимулировали формирование ткачества в период неолита. В период неолита и пришедший на его смену период энеолита ткачество стало одним из важных направлений деятельности домашних мастеров. Как известно, в то время широкое распространение получили такие направления, как обработка камня домашними мастерами, обработка кости, производство керамики, обработка кожи и шкур, обработка металлов. Собственно, развитие ткачества было тесно связано с большинством вышеперечисленных областей мастерства. Установлено наличие следов свай из глины и тростника на Култепе I недалеко от города Нахчыван и памятника Аликомектепеси в Мугане. На скелетах и на поверхности глиняных горшков в вскрытых грунтовых могилах остатки ткани и циновки. Кроме того, на глиняных полах домов поселка Аликомектепеси обнаружены остатки матов.

Ключевые слова: ткачество, археология, Культепе, Азербайджан, Кавказская Албания, античньй период, раннесредневековый период, средневековый период

\section{Introduction:}

T $\mathrm{n}$ human history invention of weaving has it's special place among significant achievements that people have obtained. According to common provision, formation of weaving is connected to the Neolithic period. As is known, significant innovations that happened in the Neolithic period and also formation of economic production(formation of agriculture and cattle-breeding) created weaving alongside starting ceramics production.Prominent english scientist Gordon Child called these significant innovations as neolithic "revolution". Appearance and development of weaving were related to objective demand of society's life. Formation of this field of art had taken important part in existance of local raw material base alongside that demand.
According to weaving, abundance of raw material reserves in Azerbaijan territories have rich development since ancient times.First of all, there are included wild technical plants as well as lagh, linen, hemp mallow, nettle and etc. Along with this, development of cattle-breeding especially weaving and existence of main raw material reserves, wool should be emphasized.

According to researches, early step of weaving was connected with simple technical habits in weaving field. Archaeologists suppose that bone tools with sharp edge which were found at "Firuz" camp in Qobustan of the Mesolithic period are related to elementary weaving. So that, actually we can't deny the fact of appearance of initial habits in weaving field before the Neolithic period.Afterwards, habits obtained in weaving stimulated formation of 
weaving in the Neolithic period.

In the Neolithic period and in the Eneolithic period that had replaced it, weaving became one of the significant fields for home craftsmen. As is known, at that time fields as home craftsmen's stoneprocessing, boneprocessing, ceramics production, leather and peltprocessing, metalprocessing were spread widely. Actually, development of weaving was closely connected with most of above said fields of craftsmanship.

There were found many tools of weaving in most of monuments of the Eneolithic period in Azerbaijan. We meet plenty of conical spindle tips from clay in monuments at Babadarvish, Ilanli tepe, Kultepe of the Eneolithic period and we meet them at Haji Firuz settlement in Southen Azerbaijan. Spindle tips were made from clay and bone. We can have imagination about development of weaving in Azerbaijan at that time according to fabric trace found at ceramic surface of Alikomektepesi and Kechili settlements. Along with this, at monuments of Azerbaijan of the Eneolithic period we meet other evidence, bone tools, remains of matting related to weaving (Azerbaijan Archaeology, 2008).

There was defined existance of traces of mattings made from clay and reed at Kultepe I near to Nakhchivan city and Alikomektepesi monument in Mugan. There are remains of textile and matting on sceletons and on surface of clay pots in opened ground graves. In addition, there are found remains of mattings on clay floors of buildings of Alikomektepesi settlement.

There were found special "pot stands" to dry clay pots at monuments of the Eneolithic period at the average stream of the Kura river. Those stands were woven from mattings or soft sticks. The existance of traces of matting or other weavings on ceramic stands on that zone of the Eneolithic period can be explained by this.So, we have no doubt that weaving was one of significant fields of home craftsmanship in Azerbaijan in the Eneolithic period.

Discussion: Since the Bronze Age the development of weavingentered a new phase in Azerbaijan. There were found many factic materials related to weaving at the first monuments of the Bronze Age between the second half of the IV millennium b.c. and III millennium b.c. Conical spindle tips (spinners) from stone and ceramic among them have their special place here.Generally, spinners were mainly considered for manual spindles. Afterwards, such kind of spinners among used spinning wheel spindles were considered mainly for manual spindles.

Then, such kind of spinners were not applied among used spinning wheel spindles. It is true that there were not found remains of textile at the first monuments of the Bronze Age period. But existance of remains of "weaving ceramics" related to that period helps to imagine about that. Because ceramic examples named "weaving ceramics" were found at most of monuments of the Early Bronze period of Azerbaijan (Azerbaijan Archaeology, 2008).

Those ceramic examples were found in Khankendi, Kurqanlar of Garabagh, as well as in Qarahajili, Juttepe, Uchoglan, Deyirman place settlements many times. Sign that differ this type of pots is defining weaving trace on their surfaceevidently. It was identified that, there were used fabric sacks in production of one group of clay pots. This fact proves once more that at period of "ceramic weaving" production weaving was having it's significant place in local tribes' life. Although technical plants were used in weaving in the Bronze periodin certain amount, main raw material base had been wool products. As is known, in the Early Bronze period essential quality changes happened in development of cattlebreeding.Sheep breeding as more profitable field of cattle-breeding developed rapidly.

In the first half of III millennium b.c. essential progress that happened in cattlebreeding caused the first big division of social labor which caused separation of cattle-breeder tribes from farmer tribes. And this stimulated appearance of summer pasture and nomadic cattle-breeding. In other words, in above said period development of sheep breeding created conditions for sufficient processing of wool as the main raw material reserve in weaving (Azerbaijan Archaeology, 2008).

In the Middle Bronze Age covering the first half of II millenium b.c. weaving art developed more. It is not accidental that especially in the Middle Bronze Age in all fields of craftsmanship happened significant progress. Significant changes are observed in ceramics, metallurgy,metal processing, bone and wood 
processing and even a lot of other fields of art alongside weaving. Upgrading obtained technical habits in previous centuries and need to meet the increasing demands of people among factors stimulating development of this field as well as strengthening raw materials base were having their significant place.

Existence of conical spindle tips from clay and bone, spinners, other bone and stone tools prove development of weaving in Azerbaijan in Middle Bronze period. Because of weaving looms of that time were made from wood, so we didn't meet their remains at ruins of monuments. But tools found in many monuments of the Middle Bronze Period of Azerbaijan can prove existence of such kind of looms. For example, bone pestle, kirkid and combs got from archaeological excavations at Kultepe II ancient settlement near to Nakhchivan cityshow using weaving squares in simple structure in weaving. Along with this, comb-like toothed bone tools used in process of combing wool, cleaning yarn on weaving loom, joining fabric loops and etc. were found both from Kultepe II and from Uzerliktepe ancient settlement near to Aghdam. Weaving tools made from deer horn like kirkid and heve(part of weaving loom) found in these monuments causes special interest. These types of tools are still used in Azerbaijan carpet- weaving art (Azerbaijan Archaeology, 2008; Azerbaijan Ethnography, 2007) (Fig. 6; 7).

Surely, in the Middle Bronze period development of weaving gave an opportunity to sew different clothes from wool fabric. Materials found in Gizilburun settlement near to Nakhchivan and stone box graves prove this. Figure of clay man found here was described in long cardigan and tight trousers. It had a waistband on waist, socks and shoes on feet. It had a cap sunken in the middle. Clothes were dyed in red and black colors. As we can see ancient weaving masters knew secrets of using different paints.

Making different clothes from colorful fabrics in the Middle Bronze period are proved well by man and woman pictures on polychrome painted clay vessel found at Gizilburun necropolis in Nakhchivan. Man's cardigan is black, his turban, waistband and handkerchief in hand are red. Alongside clothes, woolen yarns were used in weaving socks. Socks described by foot shaped clay products are mostly found among materials of Julfa necropolis. Socks were described in red and black color. Clothes and socks were woven by tools from bone and bronze as well as byneedle. These type of tools were found in monuments of Kultepe II, Uzerliktepe, Gizilburun and etc. of the Middle Bronze period many times.

Monuments of the Late Bronze Age and the Early Iron Age give an opportunity to know more information about development of ancient weaving in Azerbaijan. Tips of spindles, needles, different stone pendant, comb-like things made from clay, stone and bone among materials showing existence of weaving in that time have their special place. We came across with these types of tools in Mingachevir, Saritepe, Goygol, Garatepe settlements of Azerbaijan as well as in Garabagh, Ganjachay, Khachbulag mounds many times. Development of weaving in theLate Bronze Age is proven by other visual arguments. First of all, it includes fabric remains. Fabric remains were found in ground graves and mounds of Mingachevir, Borsunlu, Sarichoban and Bayimsarov mounds of Garabagh. Those fabrics were mainly woven from woolen fibers. Surely, in the Late Bronze Age and the Early Iron Age as a raw material sheep and lamb wool had their main place in weaving. But according to thought of using goat lint (goat's wool)as well as elegant and soft, high quality camel wool there were used technical plant fibers especially linen fiber alongside wool at that time. According to V. A. Petrov`s opinion, linen was widely spread since ancient times in Azerbaijan.

Linen used in the Late Bronze Age and the Early Iron Age was one of sort of wild linen still growing around Mingachevir, as well as around foothills of Small Caucasus. There were woven fabrics, socks, clothes from linen and wool fibers and there were made rope, yarn, lace and etc. too. Laces made from different fibers were found in ground graves and mounds of Mingachevir and Gakh (Torpaggala). These laces held beads, buttons from bronze or other materials and analysis of found fabric remains show that ancient weaving masters knew the secrets of this art deeply. Combining meshes to each-other by complex technical method shows existence of more complicated weaving field as carpet-weaving at that time. This type of fabric remains were found in Borsunlu 
mound of XIV-XIII centuries bc, Mingachevir and Sarichoban mounds of XII-XI centuries BC (Aslanov, 1961; Khalilov, 2009).

Although there are not found any remains of weaving loom in monuments of the Late Bronze period of Azerbaijan we can define such kind of looms with vertical and horizontal construction according to ethnographic observation. Existence of remains of fabric with complex meshes doesn't impeach existence of weaving looms in the Late Bronze period. Parts of weaving looms found in antique and early medieval period catacomb graves and settlements of Mingachevir give us an opportunity to imagine about these types of weaving looms.

We didn't come across with paint traces among found remains of fabrics. But, surely ancient weaving masters knew methods of dying yarns. As paint material different types of plants as well as marina, wormwood, walnut, pomegranate and etc. were used here. Development of weaving is proven by other arguments and existence of buttons from bronze, bone, glass in different size. We come across with these types of buttons in large quantities in monuments of Minghachevir, Goygol, Gedebey, Khachbulaq, Garabagh, Nakhchivan, Lankaran and other regions of Azerbaijan. Alongside practical importance buttons were used as ornaments and were used in decoration of different types of clothes (Mammadov, 2006; Mammadova, 1993; Mammadova, 2005; Mammadova, 2019) (Fig. 1; 3; 4).

Buttons found in graves were decorating hereafter clothes of buried ones here. The problem is that hereafter world was constructed on ancient burial tools. So, we can explain putting buttons in proper order beside and above of dead ones in graves by this. Buttons fastened on clothes found in graves, cocoon and discs being the sign of remains of different clothes show the high level of development of weaving art in the Late Bronze Age and the Early Iron Age in Azerbaijan.

\section{Conclusion.}

At that time, ancient weaving masters alongside weaving clothes wove different means of household items. There is no doubt, development of half-nomad and summer pasture cattle-breeding required formation of means of household as marfaj (box for bedding woven as rug), saddlebags, carpet-bag, sack. Such kind of means ease packing and carrying home equipment and products when people move to mountains andlowlands. Weaving rugs, carpet without pile, pile less carpet to cover floors of houses, after a while weaving carpet were mastered. Meander, crosses, rhombus, even different geometric, floral patterns, human and animal images described on the surface of ceramics of this period of Ganjachay region and Garabagh are still widely used in carpetweaving. Therefore, we dare say, history of carpet-weaving in Azerbaijan begins at least in the Late Bronze Age and the Early Iron Age. It should be noted, these pictures and patterns in Azerbaijan carpet-weaving art were used for centuries and it still continues to be as a custom through centuries (Asadov, 2018; Khalilov, 2010) (Fig. 2; 5). It was defined by researches that different types of pattern motifs in the Late Bronze Age and the Early Iron Age in Azerbaijan are similar to patterns used in Azerbaijan carpet-weaving. This fact gives an opportunity to say that carpet-weaving art appeared in the Bronze Age in Azerbaijan and evolved during thousand years (Fig. 6; 7). High development of weaving art in the Late Bronze Age and the Early Iron Age by meeting demand of local people of Azerbaijan enabled many of weaving products to become means of exchange. Probably, it enabled division of labor activity in weaving field at that time. It means, all the necessary actions from processing of wool to getting ready product were done by different professional masters. There are included different type of actions as feeding animals, shaving wool, washing, combing, making yarns, dyeing and production of final product. The last action is delivering final product to consumers. Caucasian Albanian period monuments gave us weaving materials which concern to IV BC and VIII AD. These materials unearthed during archaeological excavations of antique and early medieval period settlements and graves (Asadov, 2018; Khalilov, 2009; Khalilov, 2010; Mammadov, 2006; Mammadova, 1993; Mammadova, 2005; Mammadova, 2019). Development of these and other fields of craftsmanship in Azerbaijan caused expansion of trade relations and keeping close economic relations in environmental, especially in cultural centers of Central Asia. 

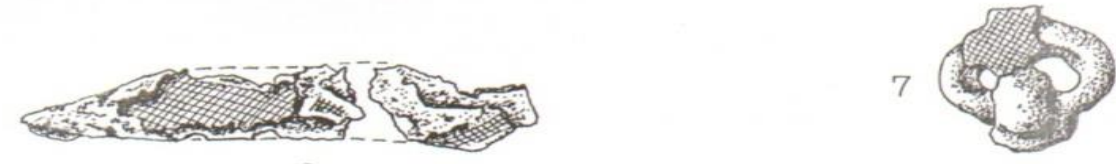

6

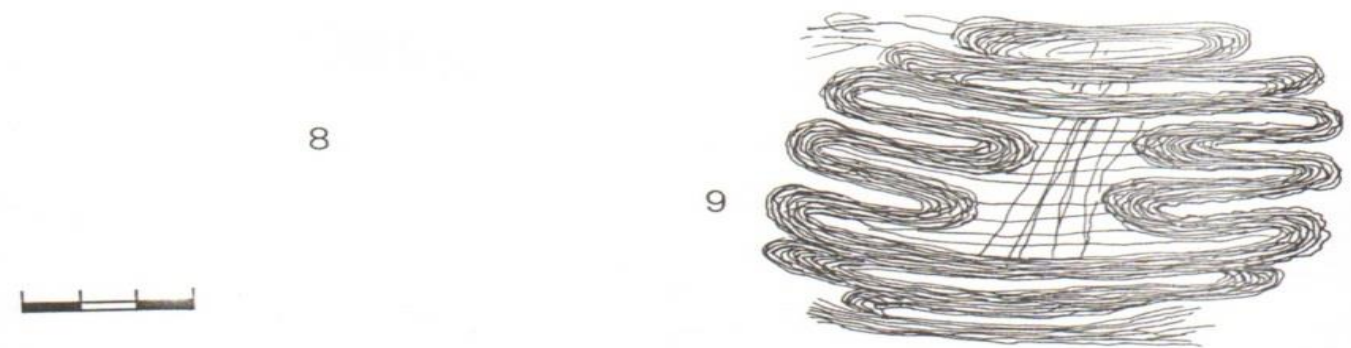

Figure 1

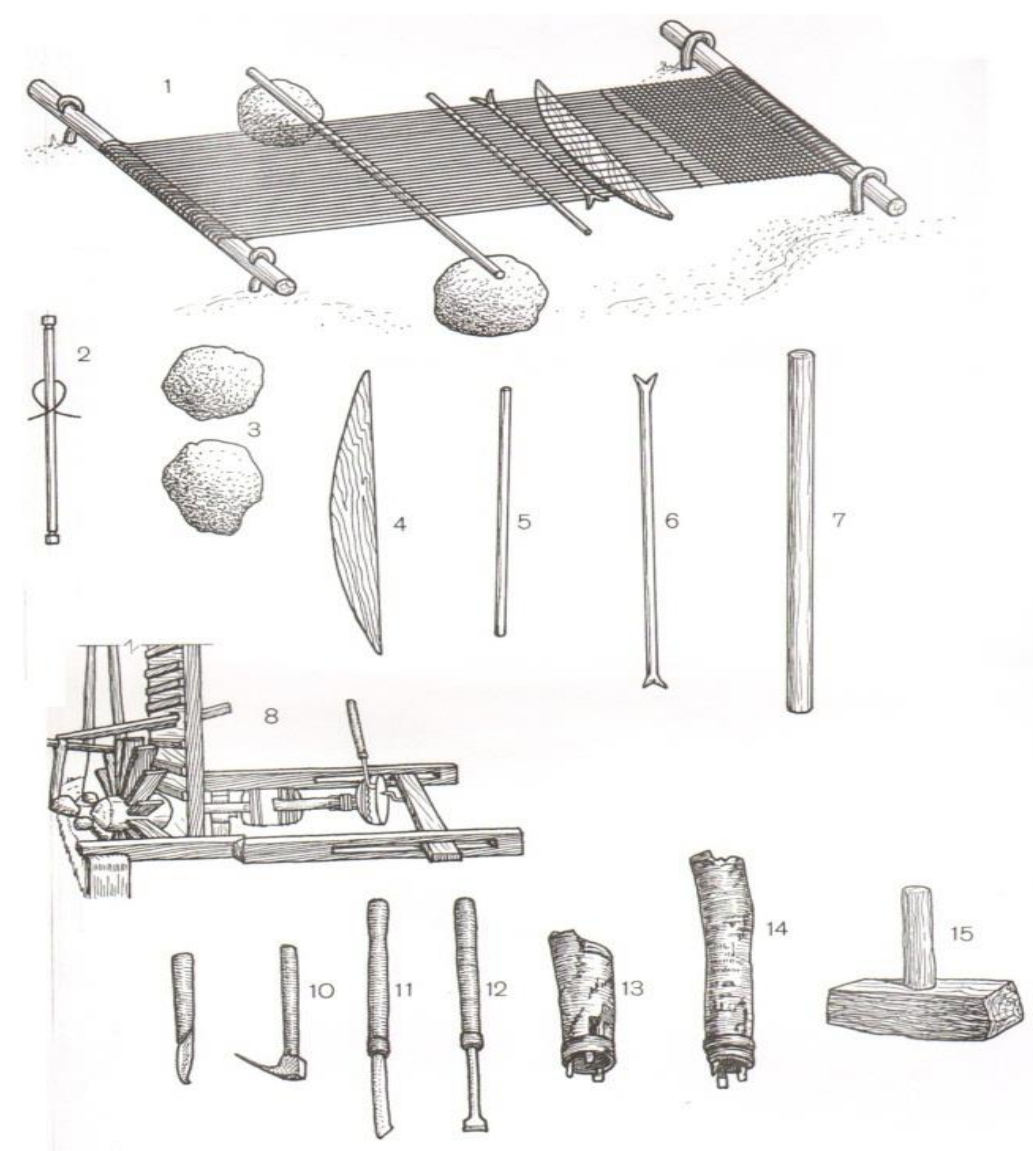

Figure 2 

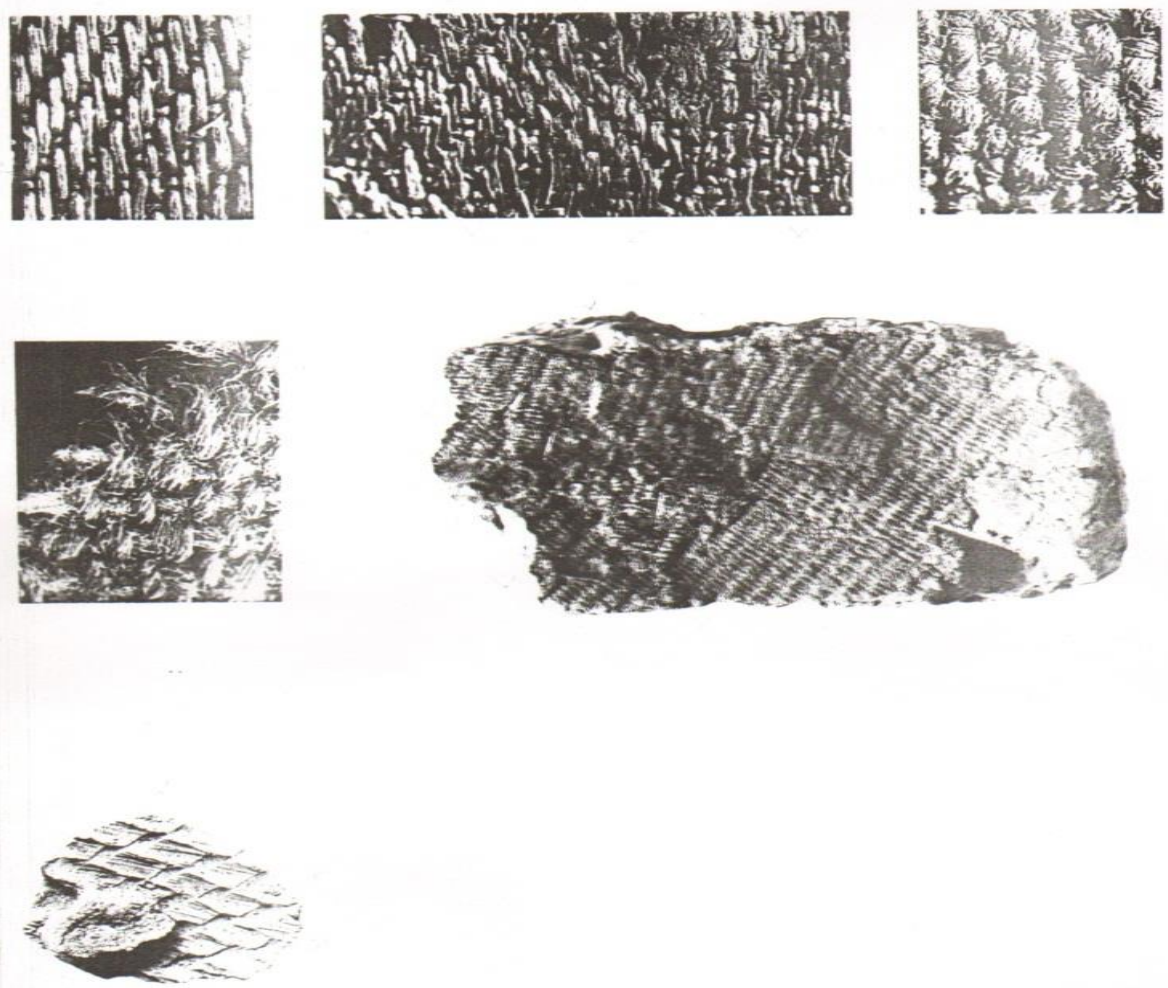

Figure 3
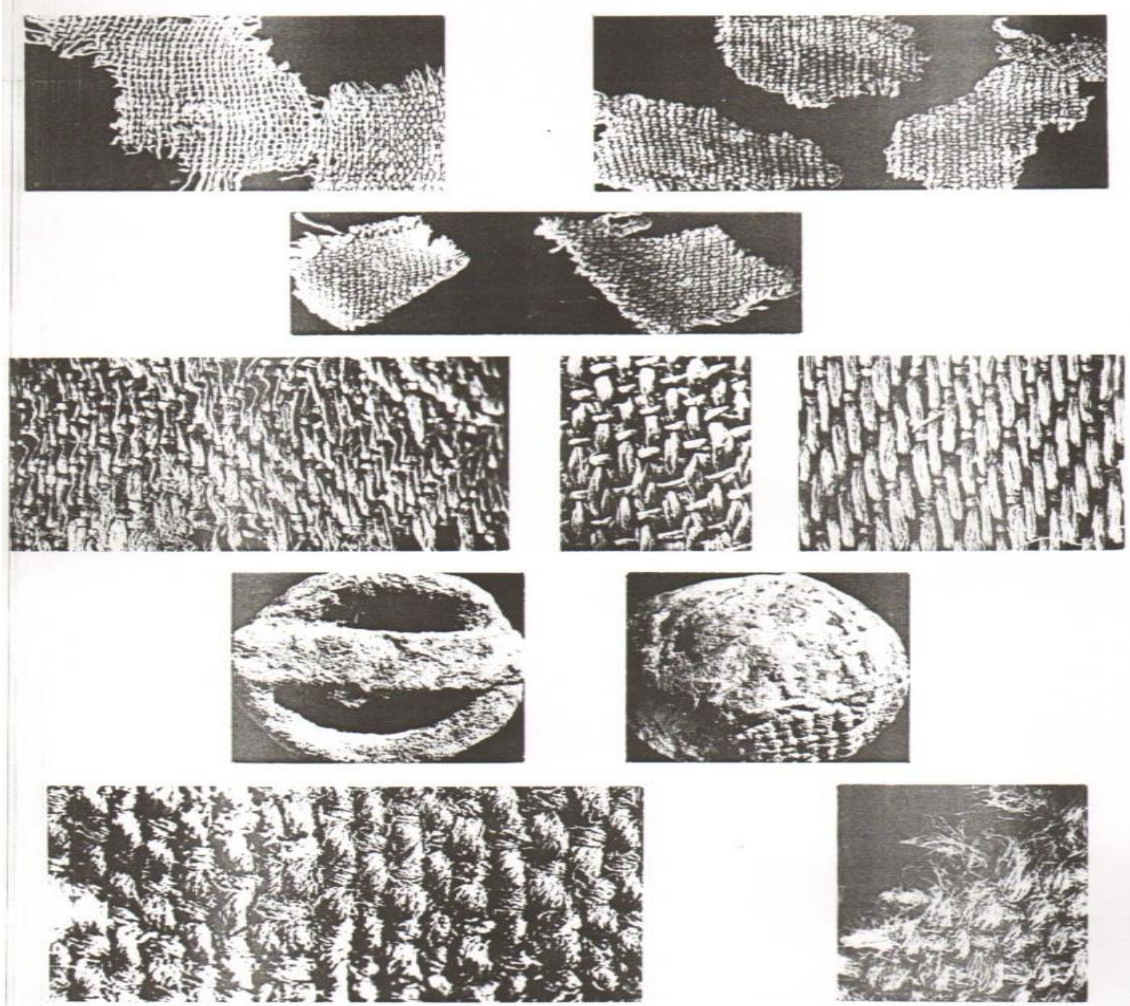

Figure 4 


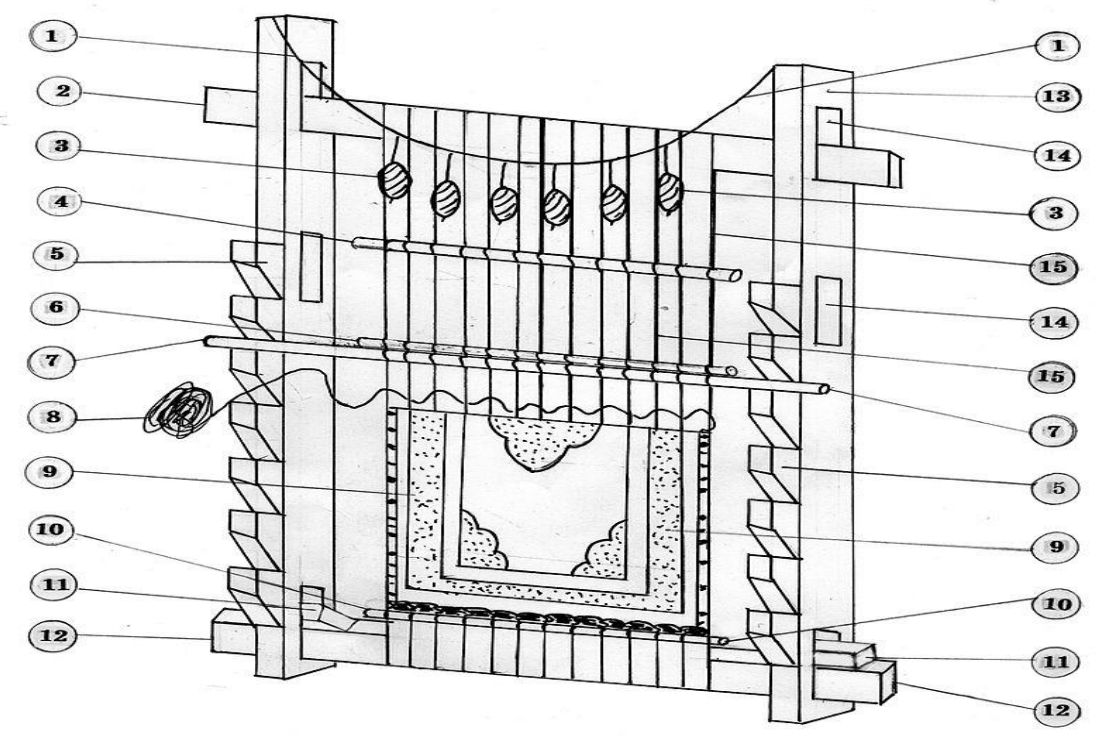

Figure 5

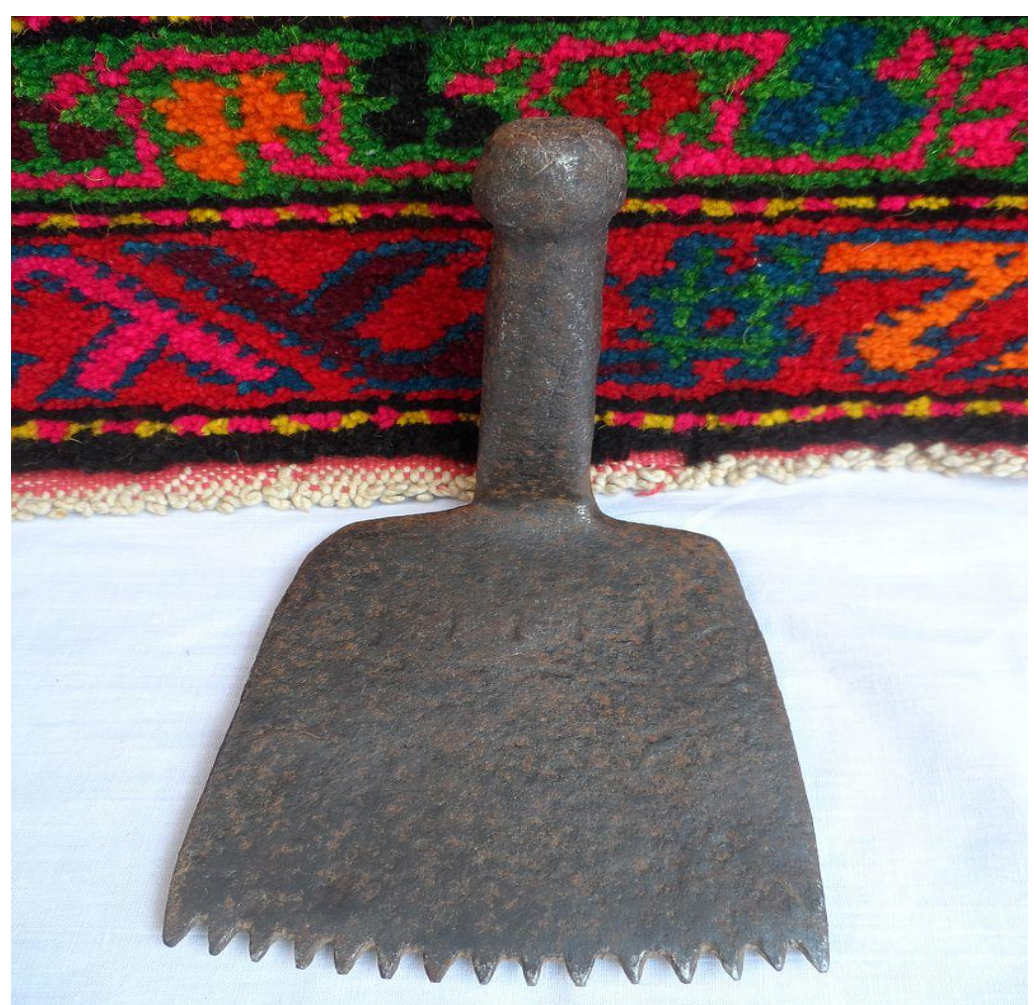

Figure 6 


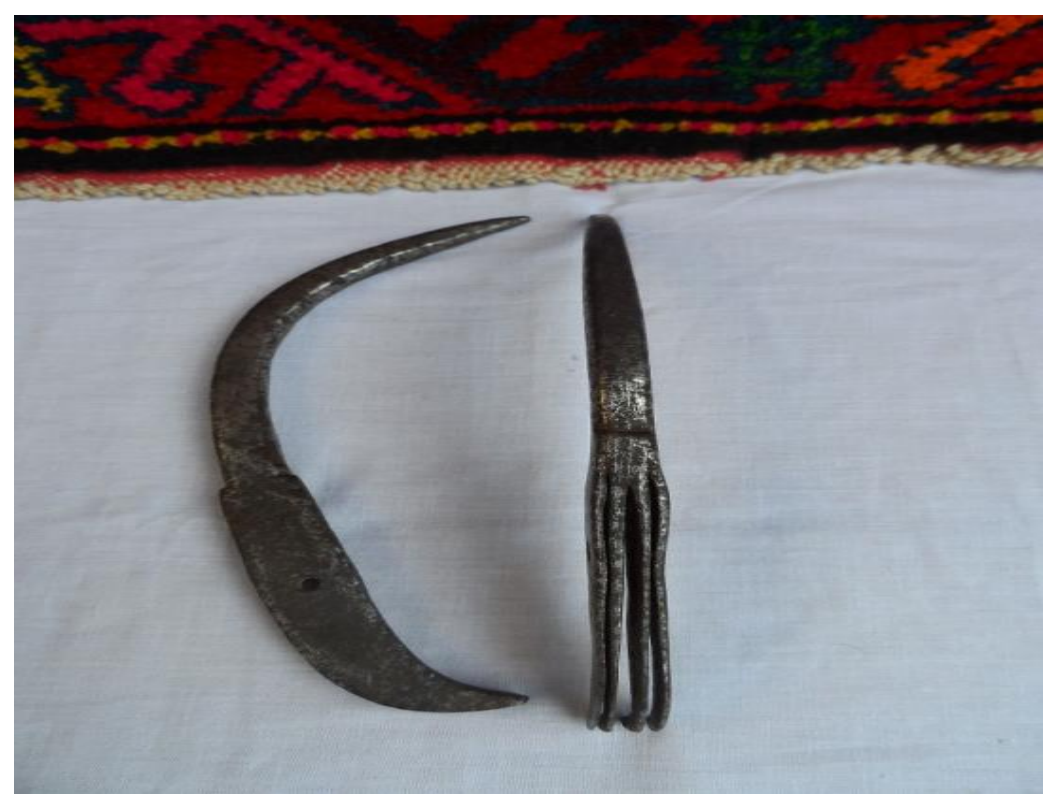

Figure 7

\section{REFERENCES}

Aslanov, S. M. (1961). Archaeological excavations in Torpaggala. News of Azerbaijan SSR AS, 8, 15-30 [in Azerbaijani].

Asadov, V. A. (2018). Jar graves of Azerbaijan. Baku [in Azerbaijani].

Azerbaijan Archaeology (in 6 part). (2008). Part VI. Baku: "East-West" [in Azerbaijani].

Azerbaijan Ethnography (in 3 part). (2007). Part III. Baku: "East-West" [in Azerbaijani].

Khalilov, M. J. (2009). Grave monuments of Albania (IV-X centuries). Baku: "Nafta-Press" [in Azerbaijani].

Khalilov, M. J. (2010). Settlements of Albania (IV-X centuries). Baku [in Azerbaijani].

Mammadov, T. M. (2006). Caucasian Albania in Early Middle Ages. Baku: "Tahsil" [in Azerbaijani].

Mammadova, F. J. (1993). Political history and historical geography of Azerbaijan (Albania) (III BC - VIII AD). Baku: "Azerneshr" [in Azerbaijani].

Mammadova, F. J. (2005). Caucasian Albania and albanians. Baku [in Russian].

Mammadova, F. J. (2019). Alban ethnocultural heritage of Azerbaijan. Ethnocultural heritage of Caucasian Albani. (pp. 9-22). Baku: "Sharg-Garb" [in Russian].

\section{Мамедова Шахла}

Докторант

Азербайджанський державний аграрний університет

\section{Mammadova Shahla}

Doctoral Candidate

Azerbaijan State Agricultural University

Email: rus_rahimli@yahoo.com

ORCID: 0000-0002-5311-8729

Цитування: Мамедова, Ш. (2020). Історія ткацтва в Азербайджані. Науково-теоретичний альманах «Грані», 23 (9), 74-82. doi: 10.15421/172085

Citation: Mammadova, Sh. (2020). History of weaving in Azerbaijan. Scientific and theoretical almanac «Grani», 23 (9), 74-82. doi: 10.15421/172085

Стаття надійшла / Article arrived: 25.09.2020

Схвалено до друку / Accepted: 20.10.2020 